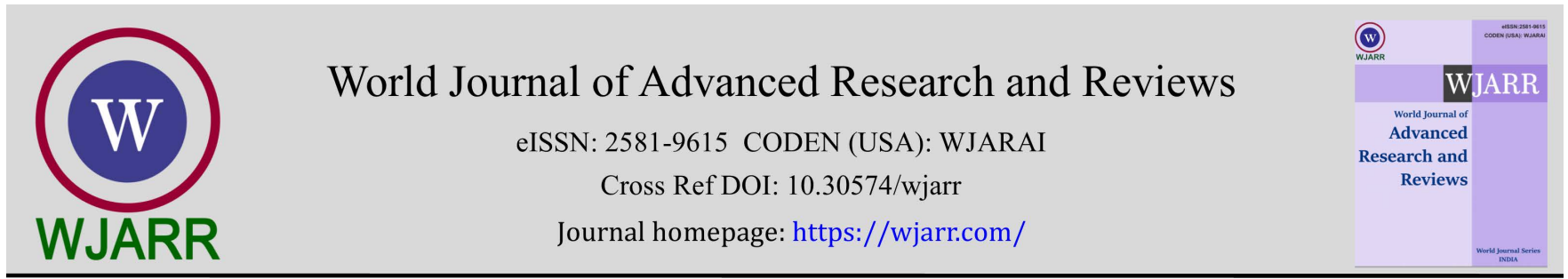

(RESEARCh ARTICLE)

\title{
The impact of the volume of sugar cane on the wages of workers in the sugarcane refinery, ketol district, Aceh central regency
}

\author{
Eliyin *, Ilma Fitri, Muhamad Yustisar, Salmandi Putra, Anna fitriana and Nurlela
}

Program Studi Agribisnis, Universitas Gajah Putih.

World Journal of Advanced Research and Reviews, 2021, 12(03), 640-644

Publication history: Received on 22 November 2021; revised on 28 December 2021; accepted on 30 December 2021

Article DOI: https://doi.org/10.30574/wjarr.2021.12.3.0738

\begin{abstract}
Sugarcane (Saccharum Offcinarum L) is one of the important commodities for making sugar which has become a necessity for industry and households. Sugarcane which is processed into sugar granules or often known as brown sugar is located in the Ketol District, Central Aceh Regency. Central Aceh Regency, especially in Ketol District, West Blang Mancung Village, is one of the sugar cane producers. Sugarcane is an annual plant that has its own characteristics, because in the stem there is sugar, sugarcane plants belong to the grass family (Gramenia) such as rice, corn and others. Linear regression analysis is an indirect approach that is used to measure the effect of the volume of sugarcane juice on the wages of workers in the sugar mill Sulaiman Ali sugarcane mill, Ketol District, Central Aceh Regency. The results of the linear regression analysis obtained from the research results are the equation $=7179,497+14,464 \mathrm{X} 1$. Where it means that every increase in the total volume of sugarcane juice by 14,464 will increase the wage income of milling workers at the Sulaiman Ali sugarcane refinery, Ketol District, Central Aceh Regency, amounting to Rp. 14,464 /person with an average income of Rp. Rp 34,656.25/person/one production process.
\end{abstract}

Keywords: Sugarcane; Nira; Labor; Wage; Rece

\section{Introduction}

The magnitude of the influence of the agricultural sector in all economic activities, both the national economy and the economy of the community. Agricultural development is an integral part of national development which aims to increase agricultural products, increase farmers' income, expand employment opportunities, encourage income and business opportunities as well as preserve natural resources and the environment [1].

The success of increasing agricultural production has involved millions of farmers in rural areas who play a role in these small business activities by utilizing available resources, both as sharecroppers, tenant farmers and farmers, or farm laborers [2]. Sugarcane (Saccharum Offcinarum L) is one of the important commodities for making sugar which has become a necessity for industry and households. Sugarcane which is processed into sugar granules or often known as brown sugar is in the Ketol District, Central Aceh Regency [3]. In Central Aceh Regency, especially in Ketol District, West Blang Mancung Village is one of the sugar cane producers. Sugarcane is an annual plant that has its own characteristics, because in the stem there is sugar, sugarcane plants belong to the grass family (Gramenia) such as rice, corn and others [4].

Sugar is one of the food needs that is very important for daily needs in households and the food and beverage industry, both large and small scale. Sugar is very important because sugar contains calories needed for health and sugar is also used as the main sweetener used by many food and beverage industries [5]. [6].

\footnotetext{
* Corresponding author: Eliyin

Program Studi Agribisnis, Universitas Gajah Putih.

Copyright $(2021$ Author(s) retain the copyright of this article. This article is published under the terms of the Creative Commons Attribution Liscense 4.0.
} 
We know that an industry will not run without the presence of workers who help the production process. Workers will also definitely receive wages for the work that has been done at a sugarcane refinery. The workforce in the sugarcane refinery is divided into two, namely grinding workers and cooking workers [7]. [8].

The sugarcane milling workers at the Sulaiaman Ali sugarcane factory are carried out by 2 men. The system for receiving wages for the sugarcane milling workers of grandmother Khatijah is carried out by means of how much volume of sugarcane juice is produced from the milling process which is multiplied by the amount of wages prevailing in the research area. This is what causes and encourages researchers to want to do research on "Analysis of the Effect of Sugarcane Nira Volume on Wages Receipts for Workers in Sugarcane Milling at the Khatijah Sugarcane Refinery, Ketol District, Central Aceh Regency".

\subsection{Material and Methods}

Most of the sucrose is stored inside the sugar cane stalk which is then extracted, it also contains antioxidants and other components contained in the sugar cane stalk (9). Stated that the juice is very easily damaged so that the juice becomes acidic, white foamy, and slimy. If the sap is cooked too late, usually the color of the sap will turn yellowish cloudy, the taste is sour and the smell is pungent [11]. The conditions and properties of this sap will determine the nature and quality of the resulting product (10). Brown sugar is the result of processed sap which is solid and reddish brown to dark brown in color. The sap used usually comes from coconut, sugar palm, palm or siwalan plants, and sugar cane (12). Brown sugar cane is sugar produced from processing or sugarcane juice (Saccharum officinarum) through concentration with or without the addition of permitted food ingredients and is brown in color (13). The principle of making brown sugar cane is the process of evaporation of juice by heating until the juice reaches a certain thickness, then printing it into the desired shape (14). Sugar is sucrose which is a monosaccharide. Namely D-Glucose and DPructose. Sucrose has caramelization properties which results are called caramel (Anonymousa 2009). Sucrose in the form of heated water will become glucose and prictose which is called sugar (15).

The formation of brown sugar color is influenced by two factors, namely the condition of the raw material (sap) and the manufacturing process. The condition of the sap in question is the condition of the sap (fresh or sour) and the chemical composition of the sap (water content, protein, organic acids, and fat) [16]. While the stages of the process are the process temperature, stirring during cooking, as well as the condition of the process cleanliness (sanitation), and the tools used (17). Brown sugar is the result of processed sap which is solid and reddish brown to dark brown in color. The sap used usually comes from coconut, sugar palm, palm or siwalan plants, and sugar cane (18). In addition to consumption at the household level, brown sugar is also a raw material for various food industries such as the soy sauce industry, tauco, cookie products, and various traditional food products (19).

This research was carried out at the refinery owned by Sulaiman Ali, Kampung Belang Mancung, Ketol District, Central Aceh Regency. The selection of the site was carried out purposively with certain considerations that Sulaiman Ali's refinery carried out sugarcane processing starting from the process of receiving sugar cane to turning it into brown sugar. This research was conducted from September 2020 to completion.

Simple linear regression is a process to obtain a mathematical relationship in the form of an equation between a single dependent variable and a single independent variable or in other words, linear regression involving only one independent variable $\mathrm{X}$ which is associated with one dependent variable $\mathrm{Y}$. The general form of the regression model simple linear, namely: (20)

$$
\mathrm{Y}=0+1 X 1
$$

Where:

$=$ dependent variable (income)
$0=$ intercept parameter
$1=$ regression coefficient (slop)
$1=$ independent variable(volume of sugarcane juice) 


\section{Results and discussion}

This research was conducted in Ketol District and is one of the areas of Central Aceh District. The area of Ketol District is $611.47 \mathrm{KM}$ 2. Ketol District is one of the locations of agricultural land for farming. In general, most of the livelihoods are farmers, but there are also traders and employees. The area of Ketol District stretches wide and is bordered by:

- In the east, it is bordered by Kute Panang District and Bener Meriah Regency

- $\quad$ To the south, it is bordered by the Districts of Silih Nara and Rusip Antara

- In the west, it is bordered by Rusip Antara District and Pidie Regency

- In the north, it is bordered by Bireuen Regency and Bener Meriah Regency

The Sulaiman Ali Sugarcane Refinery is located in Blang Mancung Induk Village, Ketol District, Central Aceh Regency. Located on Jl. Lr. Village Head, Village. Blang Mancung, Ketol District. The boundaries of the location of the home industry for sugar cane processing owned by Sulaiman Ali are as follows:

- North side is bordered by rustam garden

- $\quad$ South side is bordered by diamond safe garden

- $\quad$ East side is bordered by wagino land

- West side is bordered by sukimin land

\subsection{A Brief History of Sulaiman Ali's Sugarcane Refinery}

The Sulaiman Ali Refinery has been established since 1993. The Sulaiman Ali Sugarcane Refinery was established at the initiative of the family of Sulaiman Ali's grandmother, the children of Sulaiman Ali, hoping that the refinery can support the family's economy, as one of the livelihoods of the Sulaiman Ali family.

The establishment of this refinery was established thanks to the proceeds from a loan from a relative, before my grandmother had thought of borrowing money from a bank to set up this business, but Sulaiman Ali's brother and family did not agree and even disagreed because they were thinking about how to cover the bank's interest. that in the future. So the family initiative asked Sulaiman Ali to just borrow money from his brother to be used as initial capital for the establishment of this refinery [21].

\subsection{Sample Characteristics}

The characteristics of the sample in milling brown sugar cane at the Sulaiman Ali sugarcane factory, Ketol District, Central Aceh Regency, are age, education, experience in sugarcane milling activities. The characteristics of the sample will determine the work ability of a person in carrying out their activities. In carrying out their work as sugar cane mill workers, the workers are expected to be of a productive age and have experience.

In terms of age, those classified as productive age are between 17-55 years. In accordance with this limitation, Sulaiman Ali's sugarcane mill workers are still in the category of productive age.

\subsection{Data Analysis}

In order to determine the effect of the volume of sugarcane juice on the receipt of wages for mill workers at Sulaiman Ali's sugarcane refinery. In this case using a simple linear regression analysis tool. The results of simple linear regression analysis are as follows;

Table 1 Analysis results

\begin{tabular}{|l|c|c|c|c|}
\hline \multicolumn{1}{|c|}{ Variable } & Regression Coefficient & Coefficient of Determination & $\boldsymbol{t}_{\text {hitung }}$ & $\boldsymbol{F}_{\text {hitung }}$ \\
\cline { 1 - 2 } Constanta & 7179.479 & \multirow{2}{*}{908} & 4.612 & \multirow{2}{*}{98.626} \\
\cline { 1 - 3 } Sugarcane Juice Volume & 14.464 & & 9.931 & \\
\hline
\end{tabular}

From the data in the table above, we can see that the regression coefficient for the volume of sugarcane juice is 14,464 , which shows that the effect of sugarcane juice volume on wages for mill workers in Sulaiman Ali's refinery is Rp. $14,464 /$ liter. 


\subsubsection{T. Test}

To see the significant level in this case, the t-test is used, where the $\mathrm{t}$-count is 9.931 , where the error rate is $=5 \%$ or 0.05 , so the t-table value is 2.228 . This shows that tcount $>$ ttable, the decision criteria we can take are reject Ho and accept $\mathrm{Ha}$, meaning that the sugarcane juice volume variable has an effect on the acceptance of wages for sugarcane milling workers at Sulaiman Ali's sugarcane refinery (significantly affects wage receipts).

\subsubsection{F Uji Test}

We can note from the analysis of variance, the ANOVA table (attachment) is obtained with an Fcount value of 98.626 and Ftable with a value of $=5 \%$ or $0.05(1: 12)$ is 4.75 . because Fcount $>$ Ftable or we can see from the probability value which is smaller than the level of confidence, namely $(0.000<0.05)$. Where it means that if Fcount $>$ Ftable then reject Ho and accept $\mathrm{Ha}$, meaning that the variable volume of sugarcane juice affects the acceptance of wages for sugarcane milling workers at Sulaiman Ali's sugarcane refinery.

\subsubsection{Simple Linear Regression Equation}

The simple linear regression equation is as follows: $\grave{Y}=\beta 0+\beta 1 \mathrm{X} 1$

The proposal is acceptable, meaning that the influence of the volume of sugarcane juice has an effect on the wages received by Sulaiman Ali's sugarcane milling workers in Belang Mancung Atas Village, Ketol District, Central Aceh Regency. So that based on the simple linear regression coefficient obtained a simple linear regression equation is as follows:

$$
\grave{Y}=7179.479+14.464 X 1
$$

After doing the analysis using a simple linear regression test. So, it is obtained that the forecast of the average income of sugar mill workers in Sulaiman Ali's sugarcane factory in Blang Mancung village, Ketol District, Central Aceh Regency is an average of Rp. 34,656/person/one production process/day [22], [23].

\subsection{Hypothesis Proving}

From the results of simple linear regression analysis used in this study. With the decision criteria that accept $\mathrm{H}_{-} \mathrm{a}$ and reject $\mathrm{H}_{-} 0$ which means that there is an influence of the dependent variable or the volume of sugarcane juice (free $\mathrm{X}$ ), on the independent variable receiving wages for milling workers (bound Y) in Sulaiman Ali's sugarcane mill in Blang Mancung village, Ketol District Central Aceh District [24], [25].

\section{Conclusion}

The results of the linear regression analysis obtained from the research results are the equation $=7179,497+14,464$ $\mathrm{X} 1$. Where it means that every increase in the total volume of sugarcane juice by 14,464 will increase the wage income of milling workers at the Sulaiman Ali sugarcane refinery, Ketol District, Central Aceh Regency, amounting to Rp. 14,464 /person with an average income of Rp. Rp 34,656.25/person/one production process.

\section{Compliance with ethical standards}

\section{Acknowledgments}

Thank you to the academic community of Gajah Putih University, especially the Agribusiness study program, who have played a role in completing research up to the stage of international journals.

\section{Disclosure of conflict of interest}

The authors declare that no competing interests exists.

\section{References}

[1] Sukardi., Tropical Commodity Bioprocess Vol. 2 No.2. Brawijaya University, Malang. Brown Sugar Cane: Opportunity to Improve Community Welfare Through Rural Agroindustry Development. Food Journal. December 2010: 19(4): 317-330. 
[2] Ananta T, Martoyo, Santoso E. Effect of Solid-Liquid Extraction on the Quality of Sugar Produced from Sulfitan Si. Indonesian Sugar Research. 1990; 2-5.

[3] Suud MH, N, Feri K, Dian H. Food Analysis. Dian Rakyat Publisher, Jakarta. Ardiansyah, A., 2007. Optimization of Carbonation for Bleaching Raw Sugar with. 2011;79-85.

[4] Muchtadi, Baharuddin, Musrizal Muin and Herniaty Bandaso. Utilization of Palm Sugar (Arenga pinnata Merr) as an Material for Making White Crystal Sugar. Perennial Journal. 2011; 3(2): 40-43.

[5] Dachlan, Diniyah, Nurud, Simon Bambang Wijanarko and Hari Purnomo. Processing Technology of Liquid Brown Sugar Nira Siwalan (Borassus flabellifer L.). Journal of Food Technology and Industry, Vol. XXIII No.1. University of Jember, Jember. 2012;1216-1228.

[6] Koge, Dubois M, Gilles KA, Hamilton JK, Rebers PA, Amith F. Calorimetric Method for Determination of Sugar of Sugars and Releated Substance. Anal Chem. 1956; 28(3): 350-356.

[7] Gehlawat JK. Membrane Technology for Sugar Industry. Academic Proceedings. 1996;67-78.

[8] Goutara and S. Wijandi. Basic Sugar Processing. Department of Agricultural Products Technology IPB, Bogor. 1975; 135-145..

[9] Fundamentals of Sugar Processing II. Department of Agricultural Products Technology. Fateta IPB, Bogor. 1985;165-176.

[10] Lutony, Tony Luqman. Sweetener Plants. Self-help spreader, Jakarta. 1993;121-129..

[11] Mathlouthi, Mohamed. Highlights of The Twentieth Century Progress in Sugar Technology and The Prospects for The 20st Century. 2000;12-28.

[12] Miller GL. Use of Dinitrosalicylic Acid Reagent for Determination of Reducing Sugar. anal. Chem. 1959; 3(3): 426428.

[13] Muchtadi TR, and Sugiyono. Food Science. PAU. Food and Nutrition. IPB, Bogor. 1992;145-157..

[14] Mochtar M, Ananta T. Some Problems and Results of Sugarcane Juice Purification. Indonesian Sugar Research. 1994; 5 -8.

[15] Ashari. Supervision of the Quality and Technology of Indonesian Sugar Manufacturing. ITB, Bandung. 1993;216226.

[16] LM Nubatonic. Study of Membrane Technology Applications in Sugarcane Juice Purification. Thesis. Graduate School. IPB, Bogor. 2004;327-334..

[17] Payne JH. Fundamental Reaction of the Clarification Process. Elsevier. Amsterdam. 1953;285-298..

[18] Plantation Research and Development Center. Sugarcane Cultivation and Post Harvest. ESKA Media, Jakarta. 2010;94-103.

[19] Sagala et. al. Completion of Manufacturing Methods and Quality Research of Palm Sugar in North Sumatra. BPK Medan Communication. 1978;201-223.

[20] Setyaningsih D, Anton A, Maya PS. Sensory Analysis for the Food and Agro Industry. IPB Press, Bogor. 2010;4348..

[21] Santoso ST. Organoleptic Assessment. IPB, Bogor. [SNI] Indonesian National Standard. 1992. Glucose Syrup. 1981;20-31..

[22] Industry Standardization. Ministry of Industry. Sudarmadji S, Haryono B, and Suhardi. Analytical Procedures for Foodstuffs and Agriculture. Liberty Publishers, Yogyakarta. 1997;143..

[23] Nurlela, Sukoyo, Agung, Bambang Dwi Argo, Rini Yulianingsih. Analysis of Effect of Processing Temperature and Degree of Brix on Physicochemical and Sensory Characteristics of Liquid Coconut Sugar with Vacuum Processing Method. Journal. 2014,56-58.

[24] Winarno, Rizal. Food Packaging Technology. IPB, Bogor. 1988,132. 